\title{
Investigating the Psychological Well-Being and Job Satisfaction Levels in Different Occupations
}

\author{
İsa Yücel İşgör ${ }^{1} \&$ Namık Kemal Haspolat ${ }^{1}$ \\ ${ }^{1}$ Faculty of Education, Erzincan University, Erzincan, Turkey \\ Correspondence: İsa Yücel İşgör, Erzincan University, Educational Sciences Department, Psychological \\ Counseling and Guidance, Turkey. E-mail: iyisgor@erzincan.edu.tr
}

Received: June 7, 2016

Accepted: July 22, $2016 \quad$ Online Published: November 27, 2016

doi:10.5539/ies.v9n12p194

URL: http://dx.doi.org/10.5539/ies.v9n12p194

\begin{abstract}
The purpose of this research was to investigate the relationship between job satisfaction and psychological well-being levels of different occupational employees (education, security, health, justice, worker, engineer, and religious official) carrying on their duties in different institutions and organizations in a mid-scale provincial center of Eastern Anatolian region in Turkey. Furthermore, the research also discussed the differentiation between psychological well-being and job satisfaction in terms of occupational areas, income levels and service period of different occupational employees. The research group included totally 348 employees including 107 female and 241 males between 21 and 64 years old. Psychological Well-Being Scale, Job Satisfaction Scale, and Personal Information Form were used as data collection tools in the research. According to the research results, a positive mid-level relationship was proved between psychological well-being levels and job satisfaction levels of the employees. In terms of occupational areas and income levels, a significant differentiation was observed between psychological well-being and job satisfaction scores of the occupational employees. Finally, no significant difference was determined between psychological well-being and job satisfaction levels of the employees.
\end{abstract}

Keywords: occupational areas, job satisfaction, psychological well-being

\section{Introduction}

Rapid increase at population in recent years, constant improvements in technology, and changes in socio-economic life have caused new occupational areas, and attributed new meanings to the current occupations, as well. Job satisfaction level and psychological well-being levels of the employees carrying on their duties especially in occupations related to educational, health, law, engineering, and religious issues are essential in terms of the productivity possible to be obtained from these occupations. Increase at the productivity to be obtained from these fundamental occupations reflects positively to the quality, peace and welfare of the society, and have effect upon the psychological well-being of the individuals, as well. In this sense, the concept of well-being is remarkable for maintaining the occupational life as more productive and qualified.

Psychological well-being of the individuals is possible to be affected from inner processes such as personality, and temperament, etc., and can also be affected from occupational factors such as occupation, working environment, and job satisfaction. The occupation individuals carry on can affect both their job satisfaction and psychological well-being. An occupational life in coherence with interests, abilities and values can positively affect the level of satisfaction from the occupation, and this positively reflects upon psychological well-being of the individuals. Employees with a positive attitude towards the occupation they carry on are happier and more satisfied with their self. On the other hand, employees with negative attitudes towards their occupation can encounter several emotional, mental and physical problems (Malasch \& Leiter, 1997; Okyay, 2009). In this sense, professional life creating the big part of life can be assessed as one of the fundamental factors of psychological well-being.

Psychological well-being has recently been discussed upon the happiness of individuals within the framework of several variables. Ryff (1989) mentioned that psychological well-being was a concept to be evaluated within the scope of positive psychology. Ryff (1989) defined psychological well-being as individuals' having the power to struggle in order to establish the balance between their life anxiety and individual and social interests. According to him, well-being should be explained through an integrative understanding benefiting from life development, 
mental health and clinical viewpoint. Being different from happiness, well-being has been discussed as individuals' effort to realize their own real potential. For that reason, he was influenced, especially in his studies related to psychological well-being, from development psychology, the concepts of self-realization, maturity, and functionality. In reference to this viewpoint, Ryff (1995) expressed that happiness was not the key message, and happiness could be as result of a good life. The factors that can be expressed as good life or psychological well-being includes positive relationships with the others, environmental domination, autonomy, life purpose, personal development and self-acceptance. According to Ryff (1995), the concept of psychological well-being was a multi-dimensional structure including the life attitudes of individuals rather than a simple combination of positive-negative emotions and life satisfaction (subjective well-being).

McGregor and Little (1998) expressed well-being as related to evaluating the meaning of life and puposes in life. According to Ryan and Deci (2001), well-being could be explained with psyhological need. According to them, basic psychological needs were autonomy, competence and establishing relationships, the skill of meeting these needs explained well-being. The concept of psychological well-being was defined as struggling for challenge, making efforts, personal development and growth by Waterman (1993).

When the concept of psychological well-being is considered together with the occupational life, it can be defined as individuals' establishing positive relationships with the people around, occupational acceptance, personal development, meeting life and occupational needs, and so realizing themselves providing the life development personally. Professional life is a process creating the big part of individuals. Feelings, thoughts and behaviors of individuals during this process can remarkably lead their well-being levels. It is possible to mention in reference to this aspect that satisfaction level individuals obtain from their occupation could significantly affect their psychological well-being. In this sense, what the concept of job satisfaction expresses is remarkable.

The concept of job satisfaction that was firstly defined and measured by Frank Taylor in 1911 was associated with economic income provided from job and rewards occupations provided to individuals (Çetin \& Özcan, 2004). Similar to Taylor; Herzberg, Mausnes, Peterson, and Capwell (1957) discussed job satisfaction as meeting the needs of individuals in their occupation such as success and recognition, and their being rewarded in a sense. Besides, Locke defined job satisfaction as a positive affective aspect occupation and occupational experiences of individuals provide them (Keser, 2006).

Kuzgun (2003) expressed job as an important structure possible to be mentioned as the identity of individuals. Occupation is a significant factor for individuals' gaining self-confidence in the society and being respected and affected. Individuals produce things in their occupation, and have the effort of opening the door of happiness obtaining satisfaction through what they produce. Job satisfaction was defined by Davis (1982) as satisfaction or dissatisfaction of the employees from what they have carried on (Şişman \& Turan, 2004). Luthans (1995) also suggested job satisfaction as a concept related to personal feelings. Luthans emphasized job satisfaction as including various dimensions such as salary and promotion (Toker, 2011). When the definition of job satisfaction concept is investigated, it is possible to consider that job satisfaction is an expression of employees' psychological health.

Different researches with similar aspects were encountered when the literature was reviewed. In their study titled as job satisfaction and psychological well-being as a predictor of job performance, Wright and Cropanzano (2000) observed that psychological well-being had a predictive effect upon job performance; however, psychological well-being had no predictive effect upon the job satisfaction. In their study carried upon with 336 iron workers, Witte (1999) proved a strong relationship between unreliability against the job and psychological well-being of the workers. In another study upon the unreliability against the job, Ashford, Lee and Bobko (1989) determined that job satisfaction significantly decreased job satisfaction. In another research, Terry, Nielsen and Perchard (1993) carried out a study upon 153 public workers, and they argued that job stress had a negative effect upon the psychological well-being and job satisfaction. It was revealed that there was a positive relationship between transformational leadership levels and job satisfaction and psychological well-being of the health employees (Nielsen, Yarker, Randall, \& Munir, 2009).

In a different study, it was determined that one of the most important organizational factors affecting the job satisfaction was salary, and the feeling of salary's not being paid according to the workload and achievement caused dissatisfaction in individuals (Sveinsdóttir, Biering, \& Ramel, 2006; Willem, Buelens, \& De Jonghe, 2007).

In the study carried out by Hart, Wearing, and Headey (1995) upon investigating the effect of police officers' daily work experiences and personality traits upon their stress and well-being levels, they determined that both negative work experiences and positive work experiences negatively affected their perceived life quality. 
Furthermore, they also proved in the study that personality traits with neuroticism and extroversion were a strong predictor of police officers' perceived life qualities. And Burke (1994) carried out a study with 828 police officers, and tested a model based upon 5 predictive variables (personal, demographical, and situational variables, stress experiences, work-family conflict, coping reactions and psychological burnout components) defined in previous studies, and revealed that the variables of work attitudes and psychological well-being variables were more strongly predicted that life style behaviors and physical health.

In their study, Yiğit, Dilmaç, and Deniz (2011) investigated job and life satisfaction of security employees in terms of age, educational level, seniority, service period, and the department variables, and they observed that job satisfaction score averages significantly differed according to age, but life satisfaction score averages did not significantly differ according to age. According to the variable of educational level, job and life satisfactions noticed to be differed significantly. In another study carried out by Karababa (2012) upon the school counselors, job satisfaction level of school counselors was observed to be a significant predictor of life satisfaction. In a study carried out by Özel (2015) upon employees working in 4 and 5 star hotels, it was determined that there was a positive significant relationship between life satisfaction and job satisfaction levels of the participants, and there were no significant differences in life and job satisfactions in terms of the worked period variables, and there were significant differences in life and job satisfactions in terms of monthly income. In his study upon the employees working in the automotive sector, Keser (2005) proved that satisfaction of employees related to the working life and their life satisfaction were mutually interacting with each other. In his study investigating the working life satisfaction and life satisfaction of the oncology nurses, Eren (2008) observed that life and job satisfaction of the nurses who were satisfied with their salary, having the opportunity of social activity and taking psychological support could reach to better levels. In another study, Mersin (2007) carried out a study with religious officials and found that as the employment period of the religious officials increased, their occupational satisfaction increased as well, and as the monthly income of the religious officials increased their job satisfaction also increased. In another study carried out with teachers, it was specified that the feeling of the salary was not enough for the effort they made had an effect decreasing the motivation and job satisfaction, and the variable teachers had the least satisfaction was salary (O. Bozkurt \& I. Bozkurt, 2008; Kuruüzüm \& Çelik, 2005). In different researches, it was determined that job satisfaction was lower in 25-30 and 47 and over age group teachers, and job satisfaction of teachers between 31 and 46 years old was higher (Adıgüzel, Ünsal, \& Karadağ, 2012; Ayan, Kocacık, \& Karakuş, 2009; Demirel \& Erdamar, 2009; Gençay, 2007; Sevimli \& Iscan, 2005; Türkçapar, 2012; Yavuzer, Karataş, \& Gündoğdu, 2007). In his study, Keskin (2008) proved that there was a negative relationship between employment periods and salary satisfaction of the teachers. As result of their study with 200 employees, Amodia et al. (2005) found a positive relationship between job satisfaction and mental health, and indicated the effect of job satisfaction upon the employees (Gündüz, Çapri, \& Gökçakan, 2013).

As seen in the literature review, previous studies were noticed to be carried out mostly upon education and health, and partly upon security employees and workers. Furthermore, the studies were also observed to be carried out upon job satisfaction and life satisfaction more. No studies discussing the several occupational groups such as education, health, security, law, public workers, and religious officials in terms of psychological well-being and job satisfaction were encountered. In this sense, this study was considered to be important for filling in this gap in the literature. Consequently, this study aimed to discuss psychological well-being and job satisfaction levels of different occupational groups in terms of different variables. This study aimed to investigate whether employees of different occupational groups differed or not in terms of their level of job satisfaction and psychological well-being levels.

\section{Method}

\subsection{Research Group}

The research was a descriptive study on relational screening model. The study population included occupational groups carrying on their duties in different institutions and organizations in a mid-scale provincial center of Eastern Anatolian Region in Turkey. The study sample included 348 employees varying between 21 and 64 years old $(\bar{X}=37.69, \mathrm{SD}=9.61)$ chosen with cluster sampling method among the study population. In the sample group, there were 98 teachers (28.2\%), 50 police officers (14.4\%), 46 health staff (doctor and nurse) $(13.2 \%), 36$ $(10.3 \%)$ justice employees (judge, prosecutor, and lawyer) 50 public workers $(14.4 \%), 34$ engineers $(9.8 \%)$, and 34 religious officials (9.8\%). Moreover, 107 (30.7\%) of the employees were female, and 241 were male (69.3\%).

\subsection{Data Collection Tools}

\subsubsection{Personal Information Form}

Personal Information Form developed by the researcher included questions aiming to determine some 
demographical properties of the employees. In the form, there were totally six questions including the information related to the occupation, age, gender, marital status, employment period, and monthly income level of the participants.

\subsubsection{Job Satisfaction Scale}

Job Satisfaction Scale used in this study was developed by Kuzgun, Sevim, and Hamamc1 (2005). The scale included 20 questions on five-point Likert type. The questions were related to the coherence of their occupational activities to their interest and abilities, taking responsibilities, and development and progress opportunities. The answers in the inventory were scored in five-point Likert type (always $=5$, often $=4$, sometimes $=3$, rarely $=2$, and never $=1$ ). The $4^{\text {th }}, 9^{\text {th }}, 10^{\text {th }}, 11^{\text {th }}, 14^{\text {th }}$ and $19^{\text {th }}$ items in the scale were organized as reverse in the scale. The lowest score possible to be taken from the test was 20 , and the highest score was 100 . As the score increased, job satisfaction increased, as well.

In order to determine the validity of the scale, factor technique developed by Kuzgun, Sevim, and Hamamc1 (2005) was used, and the scale was determined to be grouped under two factors as "Coherence to Qualifications" and "Development Eagerness." The total variance explained by two factors was $48.6 \%$; the variance explained by the first factor was $36.4 \%$, and the variance explained by the second factor was $12.2 \%$. Internal consistency coefficient was calculated for the reliability of the scale. Cronbach Alpha coefficient for the all scale was $\alpha=.90$, internal consistency coefficient for the first factor was $\alpha=.91$, and internal consistency coefficient for the second factor was $\alpha=.75$. The correlation between the each score taken from each item of the scale items and total score was over .30. Within the score of this research, internal consistency Cronbach Alpha coefficient of the scale was determined to be $\alpha=.89$.

\subsubsection{Psychological Well-Being Scale (PWBS)}

Psychological Well-Being Scale aiming to evaluate psychological well-being of individuals was developed by Ryff (1989). The scale was based upon psychological well-being model, and included 6 sub-dimensions and totally 84 items with 14 each in 6 sub-dimensions. The lowest score to be taken from the scale was 84 , and the highest score was 504. The scale was adapted into Turkish by Akın (2008), and it was noticed that internal consistency coefficients varied between .87 and .96 , and test re-test reliability varied between .78 and .97 . Within the scope of this research, internal consistency coefficient of the scale was determined to be .88 . The correlations between Psychological Well-Being Scale Turkish and original form scores were found to be $\alpha=.94$ for autonomy, $\alpha=.97$ for environmental dominance, $\alpha=.97$ for personal development, $\alpha=.96$ for positive relationships with the others, $\alpha=.96$ for life purposes, $\alpha=.95$ for self-acceptance. In exploratory factor analysis, it was noticed that $68 \%$ of total variance was explained, and the items were grouped under 6 factors. The factor loads were ranked between .30 and $\alpha=.94$. In confirmatory factor analysis, fit index values were found as $\mathrm{RMSEA}=.07, \mathrm{NFI}=.97, \mathrm{CFI}=.98, \mathrm{GFI}=.93$, and SRMR $=.06$. In this study, internal consistency Cronbach Alpha coefficient of the scale was determined to be $\alpha=.79$.

\subsection{Process}

Into the research, individuals carrying on their duties in different institutions and organizations in a mid-scale provincial center of Eastern Anatolian Region in Turkey in 2015 were included. Ethical approval was obtained from the relevant committees before the research. Personal Information Form, Psychological Well-Being Scale and Job Satisfaction Scale were performed to the participants in order to collect data. As result of the implementation, 360 occupational employees answered relevant scale and forms. At the end of controlling the answered scale and forms one by one, 9 employees were determined to answer some of the scale and left some others as blank. Furthermore, 3 employees were determined to mark the same choices in all items of the scale. Considering that these could affect the reliability and validity of the research, forms of these 12 employees were excluded from the implementation.

\subsection{Data Analysis}

The data were evaluated by the researcher. Obtained data were turned into the tables creating data-processing coding tables. These data were transferred into SPSS 22 statistical software, and analyzed through the statistical techniques proper to the experiments. In analysis of the data, statistical techniques such as percentage, frequency, correlation, and one-way variance analysis (ANOVA) were used. The results were tested at $\mathrm{p}<0.05$ level of significance. The scales were filled in almost 45 -minute one session by the participants.

\section{Findings}

Within the scope of the descriptive statistics; average, standard deviation, skewness-kurtosis coefficients and correlation results between psychological well-being and job satisfaction levels related to the variables of the 
research were presented in Table 1.

Table 1. Average, standard deviation and skewness-kurtosis values related to the study variables $(\mathrm{N}=348)$

\begin{tabular}{lccccccccccc}
\hline & \multirow{2}{*}{} & \multicolumn{2}{c}{ PWB } & \multicolumn{2}{c}{ JS } & \multicolumn{2}{c}{ Age } & \multicolumn{2}{c}{ Monthly Income } & \multicolumn{2}{c}{ Professional Time } \\
\cline { 2 - 11 } & & $\bar{X}$ & SD & $\bar{X}$ & SD & $\bar{X}$ & SD & $\bar{X}$ & SD & $\bar{X}$ & SD \\
\hline Education & 98 & 350.93 & 37.07 & 74.7 & 10.55 & 39.56 & 10.21 & $3.030,00 \mathrm{TL}$ & 365.6 & 16.11 & 10.13 \\
\hline Security & 50 & 358.86 & 40.39 & 69.06 & 11.88 & 36.62 & 7.29 & $3.330,00 \mathrm{TL}$ & 908.12 & 13.12 & 6.55 \\
\hline Health & 46 & 360.3 & 28.42 & 63.76 & 13.04 & 32.97 & 5.84 & $3.166,00 \mathrm{TL}$ & 1072.3 & 10.58 & 7.44 \\
\hline Justice & 36 & 370.77 & 35.07 & 80.25 & 8.21 & 37.38 & 8.53 & $5.955,00 \mathrm{TL}$ & 1460.4 & 11.8 & 10.32 \\
\hline Worker & 50 & 330.82 & 52.8 & 64.86 & 9.66 & 42.9 & 10.46 & $2.256,00 \mathrm{TL}$ & 593.9 & 16.76 & 12.1 \\
\hline Engineer & 34 & 364.11 & 33.98 & 70.91 & 11.59 & 32.35 & 6.5 & $3.450,00 \mathrm{TL}$ & 610.63 & 8.35 & 6.35 \\
\hline Religious Official & 34 & 344.94 & 34.13 & 82.44 & 10.62 & 38.29 & 11.99 & $2.441,00 \mathrm{TL}$ & 957.85 & 13.14 & 10.59 \\
\hline Skewness & & -0.898 & & -0.247 & & & & & & \\
\hline Kurtosis & & 0.904 & & -0.277 & & & & & & \\
\hline
\end{tabular}

PWB: Psychological Well-Being, JS: Job Satisfaction.

When Table 1 was analyzed, it was possible to mention that deviation from normality was not significant because skewness and kurtosis coefficients had a value at \pm 1 interval in descriptive statistics related to the variables (Çokluk, Şekercioğlu, \& Büyüköztürk, 2010; Kline, 2015). Moreover, the highest average among the psychological well-being averages were noticed to be for justice employees (370.77), and the lowest average was related to public employees (330.82) in Table 1. In terms of job satisfaction scores, the highest average was observed to be for religious officials (82.44), and the lowest average was related to the health employees. The occupational group with the highest age average was determined to be public workers with 42.9 average, and the group with the lowest age average was related to the engineers with 32.35 average. In terms of monthly income, the occupational group with the highest income was related to justice employees with 5.955,00 TL, and the group with the lowest income level was related to the public workers with 2.256,00 TL average. Finally, in terms of the professional time, whereas the public workers were noticed to have the highest average (16.76), the occupational group with the lowest professional time average was determined to be related to the engineers (8.35).

In accordance with the research findings, the relationship between psychological well-being and job satisfaction was tested with correlation analysis. And the differentiation between occupational groups, income, professional time, marital status and psychological well-being and job satisfaction levels was tested using one-way variance analysis (ANOVA). The correlation between psychological well-being and job satisfaction levels of the employees was presented in Table 2.

Table 2. The correlation between psychological well-being levels and job satisfaction levels of the occupational employees $(\mathrm{N}=348)$

\begin{tabular}{llll}
\hline Scales & & 1 & 2 \\
\hline 1 & Psychological Well-Being (PWB) & - & $.49^{* *}$ \\
\hline 2 & Job Satisfaction (JS) & - & - \\
\hline$* * \mathrm{p}<.01$ & &
\end{tabular}

When Table 2 was analyzed, the correlation coefficient between psychological well-being levels and job satisfaction levels of the employees was noticed to be $(\mathrm{r}: .49, \mathrm{p}=.000)$. According to this result, a positive mid-level relationship at .01 level was determined between psychological well-being levels and job satisfaction levels. 
One-way variance analysis (ANOVA) was performed in order to test the difference between psychological well-being and job satisfaction levels in terms of the occupational groups of the employees. In ANOVA analysis, Levene test was primarily performed in order to test the homogeneity of the groups' variances. As result of the Levene test, the variances were proved to be homogeneous. In this sense, post-hoc method used when the variances were homogeneous in post-hoc analyses related to the source of the difference was preferred. The analysis results were presented in Table 3.

Table 3. ANOVA results of occupational employees' psychological well-being and job satisfaction levels according to the occupational groups

\begin{tabular}{|c|c|c|c|c|c|c|c|}
\hline Source of the Variance & & Sum of Squares & $\mathrm{SD}$ & $\begin{array}{l}\text { Average } \\
\text { Squares }\end{array}$ & of $\mathrm{F}$ & $\mathrm{p}$ & $\begin{array}{l}\text { Significant } \\
\text { Difference (Turkey) }\end{array}$ \\
\hline \multirow{3}{*}{$\begin{array}{l}\text { Psychological } \\
\text { Well-Being }\end{array}$} & Between Groups & 46962.548 & 6 & 7827.091 & \multirow{3}{*}{5.276} & \multirow{3}{*}{$.001 * *$} & \multirow{3}{*}{$1,2,3,4,6-5$} \\
\hline & In-Group & 505848.406 & 341 & 1483.426 & & & \\
\hline & Total & 552810.954 & 347 & & & & \\
\hline \multirow{3}{*}{ Job Satisfaction } & Between Groups & 13017.479 & 6 & 2169.580 & \multirow{3}{*}{18.279} & \multirow{3}{*}{$.001 * *$} & \multirow{3}{*}{$\begin{array}{l}2,3,5,7-1 \quad 2,3,5,6 \\
4,7\end{array}$} \\
\hline & In-Group & 40473.496 & 341 & 118.691 & & & \\
\hline & Total & 53490.974 & 347 & & & & \\
\hline
\end{tabular}

**Significant at the level of $\mathrm{p}<.01$.

As result of the ANOVA analysis, a significant difference was determined between psychological well-being scores in terms of the occupational groups of the employees $\left[F_{(6-341)}=5.276, \mathrm{p}<.01\right]$. In order to test among which groups there was significant differences between psychological well-being scores in terms of the occupational groups, Post-Hoc analysis was performed. As result of the analysis, it was determined that psychological well-being score averages for teachers was $\left(\bar{X}_{1}=350.93\right)$, score averages for police officers was $\left(\bar{X}_{2}=358.86\right)$, score average for health staff was $\left(\bar{X}_{3}=360.30\right)$, score average for justice employees was $(\bar{X}$ $\left.{ }_{4}=370.77\right)$, score average for public workers was $\left(\bar{X}_{5}=330.82\right)$, score average for engineers was $\left(\bar{X}_{6}=364.11\right)$, and score average for religious officials was $\left(\bar{X}_{7}=344.94\right)$. As result of the Turkey multiple comparison test, the significant difference was specified to be between teachers, police officers, health staff, justice employees and engineers and workers. In other words, psychological well-being scores of teachers, police officers, health staff, justice employees and engineers were noticed to be significantly higher rather than the scores of the workers.

The effect size calculated as result of the test $\left(\eta^{2}=.084\right)$ proved this difference to have a mid-level effect size (Green \& Neil, 2005). It was also found that there was a significant difference between job satisfaction levels of the occupational employee groups $\left[F_{(6-341)}=18.279, \mathrm{p}<.01\right]$. Post-Hoc analysis was performed in order to test among which groups there was a significant difference between the job satisfactions scores among the occupational groups. At the end of the analysis, in terms of the occupational groups, job satisfaction score averages were determined to be $\left(\bar{X}_{1}=74.70\right)$ for teachers, $\left(\bar{X}_{2}=69.06\right)$ for police officers, $\left(\bar{X}_{3}=63.76\right)$ for health staff, $\left(\bar{X}_{4}=80.25\right)$ for justice employees, $\left(\bar{X}_{5}=64.86\right)$ for public workers, $\left(\bar{X}_{6}=70.91\right)$ for engineers, and $\left(\bar{X}_{7}=82.44\right)$ for religious officials. As result of the Turkey multiple comparison test, a significant difference in favor of teachers between police officers, health staff, workers, teachers and religious officials, and in favor of religious officials between teachers and religious officials were determined. A significant difference was also found in favor of justice employees and religious officials between security staff, health staff, public workers and 
engineer and justice employees. The effect size calculated at the end of the test $\left(\eta^{2}=.243\right)$ indicated this difference to have a broad effect size.

One-way variance analysis (ANOVA) was performed in order to test the difference between psychological well-being and job satisfaction levels in terms of the income levels of the occupational groups. In ANOVA analysis, Levene test was primarily performed in order to test the homogeneity of the groups' variances. As result of the Levene test, the variances were proved to be homogeneous. In this sense, post-hoc method used when the variances were homogeneous in post-hoc analyses related to the source of the difference was preferred. The analysis results were presented in Table 4.

Table 4. ANOVA results of occupational employees' psychological well-being and job satisfaction levels according to the monthly income

\begin{tabular}{|c|c|c|c|c|c|c|c|}
\hline Source of the Variance & & Sum of Squares & $\mathrm{SD}$ & $\begin{array}{l}\text { Average of } \\
\text { Squares }\end{array}$ & $\mathrm{F}$ & $\mathrm{p}$ & $\begin{array}{l}\text { Significant } \\
\text { Difference (Turkey) }\end{array}$ \\
\hline \multirow{3}{*}{$\begin{array}{l}\text { Psychological } \\
\text { Well-Being }\end{array}$} & Between Groups & 80561.731 & 2 & 40280.865 & \multirow{3}{*}{29.427} & \multirow{3}{*}{$.001 * *$} & \multirow{3}{*}{$\begin{array}{l}2,3-1 \\
2-3\end{array}$} \\
\hline & In-Group & 472249.223 & 345 & 1368.838 & & & \\
\hline & Total & 552810.954 & 347 & & & & \\
\hline \multirow{3}{*}{ Job Satisfaction } & Between Groups & 6745.342 & 2 & 3372.671 & \multirow{3}{*}{24.892} & \multirow{3}{*}{$.001 * *$} & \multirow{3}{*}{$1,2-3$} \\
\hline & In-Group & 46745.632 & 345 & 135.495 & & & \\
\hline & Total & 53490.974 & 347 & & & & \\
\hline
\end{tabular}

** Significant at the level of $\mathrm{p}<.01$.

As result of the ANOVA analysis, a significant difference was determined between psychological well-being scores in terms of the income level of the occupational employee groups $\left[F_{(2-345)}=29,427, \mathrm{p}<.01\right]$. Post-Hoc analysis was performed in order to test among which groups there were significant differences between the psychological well-being scores in terms of the income level. At the end of the analysis, psychological well-being score averages of the employees was determined as $\left(\bar{X}_{1}=327.50\right)$ for the low level, as $\left(\bar{X}_{2}=349.61\right)$ for the medium level, and as ( $\bar{X}_{3}=380.40$ ) for the high level. As result of the Turkey multiple comparison test, a significant difference in favor of medium and high level was determined between low, medium and high level. Furthermore, a significant difference in favor of high level was also determined between medium level and high level. The effect size calculated at the end of the test $\left(\eta^{2}=.145\right)$ indicated this difference to have a broad effect size. There was also a significant difference between the job satisfaction scores in terms of the income level of the occupational groups $\left[F_{(2-345)}=24,892, \mathrm{p}<.01\right]$. Post-Hoc analysis was performed in order to test among which groups there were significant differences between the job satisfaction scores in terms of the income level. At the end of the analysis, job satisfaction score averages of the occupational groups in terms of the income level was determined to be $\left(\bar{X}_{1}=68,40\right)$ for low level, to be $\left(\bar{X}_{2}=70,05\right)$ for medium level, and to be $\left(\bar{X}_{3}=80,78\right)$ for the high level. As result of the Turkey multiple comparison test, a significant difference in favor of high level was determined between low, medium and high level. The effect size calculated at the end of the test $\left(\eta^{2}=.126\right)$ indicated this difference to have a medium level effect size.

One-way variance analysis (ANOVA) was performed in order to test the difference between psychological 
well-being and job satisfaction levels of the occupational groups in terms of professional time, and the analysis results were presented in Table 5 .

Table 5. ANOVA results of occupational employees' psychological well-being and job satisfaction levels according to the professional time

\begin{tabular}{|c|c|c|c|c|c|c|}
\hline Source of the Variance & & Sum of Squares & $\mathrm{SD}$ & Average of Squares & $\mathrm{F}$ & $\mathrm{p}$ \\
\hline \multirow{3}{*}{ Psychological Well-Being } & Between Groups & 4985.815 & 2 & 2492.907 & \multirow{3}{*}{1.570} & \multirow{3}{*}{.210} \\
\hline & In-Group & 547825.139 & 345 & 1587.899 & & \\
\hline & Total & 552810.954 & 347 & & & \\
\hline \multirow{3}{*}{ Job Satisfaction } & Between Groups & 176.675 & 2 & 88.338 & \multirow{3}{*}{.572} & \multirow{3}{*}{.565} \\
\hline & In-Group & 53314.299 & 345 & 154.534 & & \\
\hline & Total & 53490.974 & 347 & & & \\
\hline
\end{tabular}

At the end of the ANOVA analysis, no significant difference was noticed between psychological well-being $\left[F_{(2-345)}=1.570, \mathrm{p}>.01\right]$ and job satisfaction $\left[F_{(2-345)}=.572, \mathrm{p}>.01\right]$ scores of the occupational groups in terms of the professional time.

\section{Discussion}

This study investigated the relationship between psychological well-being levels and job satisfaction levels of the occupational groups (education, security, health, justice, worker, engineer and religious officials) carrying on their duties in different institutions and organizations. The research also discussed the differentiation between psychological well-being and job satisfaction levels in terms of occupational areas, income levels, and professional time of the different occupational groups. According to the first finding of the study, a positive significant mid-level relationship was determined between psychological well-being levels and job satisfaction levels of the different occupational groups. Similar to the research finding, Amodia et al. (2005) carried out a study with 200 employees, and found at the end of the research that there was a positive relationship between job satisfaction and mental health (Gündüz et al., 2013). In another similar study, Karababa (2012) carried out a study with school counselors, and proved that job satisfaction levels of the school counselors was an important predictor of their job satisfaction level. Özel (2015) observed in his study with the employees of 4 and 5 star hotels that there was a significant and positive relationship between life satisfaction and job satisfaction levels of the employees. In contrast to the research findings, Wright and Cropanzano (2000) proved in his study titled as job satisfaction and psychological well-being as the predictor of job performance that psychological well-being had a predictive effect upon the job performance; however, psychological well-being had no predictive effect upon the job satisfaction.

In another finding obtained from the research, psychological well-being levels of the teachers, police officers, health staff, justice employees and engineers were determined to be significantly higher rather than the psychological well-being levels of the public workers. When the literature was reviewed, no studies apart from this discussing the psychological well-being in different occupational groups in a similar way were encountered. The research findings in this sense were discussed under the light of studies discussing the occupational groups separately. Obtaining such a finding at the end of the research could be associated with the salary occupational groups obtained from their jobs. A directly proportional interaction was possible to be mentioned as present between the monthly salary obtained from the job and psychological well-being level. In fact, there were research results with a quality supporting this result (Dost, 2007; Easterlin, 1974; Özel, 2015). Related to the effect of occupational difference upon the job satisfaction scores, job satisfaction averages of teachers, religious officials and justice employees were determined to be significantly higher rather than the job satisfaction averages of the other occupational groups. Job satisfaction averages of the justice employees were significantly higher rather than the averages of the other occupational groups, and this could be associated with justice employees' having higher monthly income levels rather than the other occupational groups ( $\left.\bar{X}_{4}=5.955,00 \mathrm{TL}\right)$. Indeed, there were similar research findings proving that monthly income level increased the job satisfaction of occupational groups (O. Bozkurt \& I. Bozkurt, 2008; Kuruüzüm \& Çelik, 2005; Mersin, 2007; Özel, 2015; 
Sveinsdóttir et al., 2006; Teltik, 2009; Willem et al., 2007). Although monthly income level did not differ significantly, job satisfaction averages of teachers and religious officials were significantly higher rather than the job satisfaction averages of the other occupational groups, and this could be associated with the inner satisfaction of these two occupational groups.

Another finding obtained from the research was related to the fact that psychological well-being scores of the occupational groups differed significantly in terms of occupational groups' income levels. Psychological well-being averages of the employees with medium and high level monthly income level were significantly higher rather than the psychological well-being averages of the employees with low level monthly income level. Furthermore, psychological well-being of the employees with high level monthly income was determined to be higher rather than the employees with medium level monthly income. It was revealed in similar studies in a way supporting this research finding that income level was directly proportional with the psychological well-being (Diener \& Oishi, 2000; Dost, 2007; Easterlin, 1974; Ferrer-i-Carbonell, 2005; Frey \& Stutzer, 2010; Lucas \& Schimmack, 2009; Özel, 2015). A significant difference was also specified between job satisfaction levels in terms of the income level of the employees. At the end of the research, it was observed that high monthly income level significantly increased job satisfaction of the employees. This relationship between job satisfaction level and monthly income level was also revealed in several research findings (Bodur, 2002; Judge, Piccolo, Podsakoff, Shaw, \& Rich, 2010; Kağan, 2010; Malka \& Chatman, 2003).

According to the last finding of the research, it was noticed that there was no significant difference between psychological well-being and job satisfaction scores of the employees in terms of the professional time. In literature review, different results related to the well-being and job satisfaction of the employees in terms of their professional service time were determined. In their study upon life and job satisfaction of the police officers, Yiğit et al. (2011) observed that there was a significant difference in job satisfactions core averages of the security staff according to the variable of service period, but there was no significant difference in life satisfaction score averages. In a research finding obtained by Baştemur (2006), it was proved that there was no statistically significant difference between job satisfaction and professional time. In another study upon the employees of four and five star hotels, Özel (2015) proved that there was no significant difference between life and job satisfaction levels of the employees in terms of the professional service time. These findings were noticed to be supporting the findings of our research. However, studies revealing the contrast of the research findings were also found to be present in the literature. Mersin (2007) found in his study that as the employment period of the religious officials increased, their job satisfaction increased as well. Fosam, Grimsley, and Wisher (1998) carried out a study upon English police officers, and argued that the employees who carried out their duty in their occupation for less than two years had higher job satisfaction levels rather than the ones who worked for more than two years. In other studies carried out in this sense (Adıgüzel et al., 2012; Ayan et al., 2009; Demirel \& Erdamar, 2009; Gençay, 2007; Sevimli \& Iscan, 2005; Sezer, 2013;Türkçapar, 2012; Yavuzer et al., 2007), it was noticed that job satisfaction of the teachers who had just started their profession was higher rather than the job satisfaction of the teachers who were in the mids of their professional life.

Consequently, in reference to the relationship between psychological well-being and job satisfaction within the framework of the findings obtained from the research, it could be suggested that professional orientation should be provided more qualified and professionally in order to increase the psychological well-being of the individuals. Improvements in income levels in order to increase the job satisfaction of the employees could also be offered as another suggestion. Studies related to increasing the inner satisfaction of the employees could be planned by their departments. Furthermore, the relationship between job satisfaction and psychological well-being could be investigated with different variables and sample groups.

\section{References}

Adıgüzel, Z., Ünsal, Y., \& Karadağ, M. (2012). Fen ve teknoloji öğretmenlerinin dış kaynaklı iş tatmin düzeylerinin bazı demografik değişkenlere göre incelenmesi. [An Investigation on the Levels of Extrinsic Job Satisfactions of Science and Technology Teachers Accirding to Some Demographic Variables] Dicle Üniversitesi Ziya Gökalp Ë̆itim Fakültesi Dergisi, 18, 133-155.

Ashford, S. J., Lee, C., \& Bobko, P. (1989). Content, cause, and consequences of job insecurity: A theory-based measure and substantive test. Academy of Management journal, 32(4), 803-829. https://doi.org/10.2307/256569

Ayan, S., Kocacık, F., \& Karakuş, H. (2009). Lise öğretmenlerinin iş doyumu düzeyi ile bunu etkileyen bireysel ve kurumsal etkenler: Sivas merkez ilçe örneği. [Job Satisfaction Levels of High School Teachers and Affecting Personal and Institutional Factors: A Study of Sivas City] Anadolu Psikiyatri Dergisi, 10(1), 
18-25.

Bodur, S. (2002). Job satisfaction of health care staff employed at health centres in Turkey. Occupational medicine, 52(6), 353-355. https://doi.org/10.1093/occmed/52.6.353

Bozkurt, Ö., \& Bozkurt, İ. (2008). Işs tatminini etkileyen işletme içi faktörlerin eğitim sektörü açısından değerlendirilmesine yönelik bir alan araştırması [A Field Study on Job Satisfaction Effecting Internal Factors in Education System].

Burke, R. J. (1994). Stressful events, work-family conflict, coping, psychological burnout, and well-being among police officers. Psychological Reports, 75(2), 787-800. https://doi.org/10.2466/pr0.1994.75.2.787

Çetin, M., \& Özcan, K. (2004). Okul yöneticilerinin etik davranışlarının öğretmenlerin iş doyumuna etkisi. [Influence of School Administrators' Ethic Behaviors on Teachers' Job Satisfaction] M. ̈. Atatürk Ë̆itim Fakültesi Ĕgitim Bilimleri Dergisi, 20, 21-38.

Çokluk, Ö., Şekercioğlu, G., \& Büyüköztürk, Ş. (2010). Sosyal bilimler için çok değişkenli istatistik: SPSS ve LISREL uygulamaları [Multi-Variable Statistics for Social Sciences: SPSS and LISREL Implementations] : Pegem Akademi.

Demirel, H., \& Erdamar, G. K. (2009). Examining the relationship between job satisfaction and family ties of Turkish primary school teachers. Procedia-Social and Behavioral Sciences, 1(1), 2211-2217. https://doi.org/10.1016/j.sbspro.2009.01.389

Diener, E., \& Oishi, S. (2000). Money and happiness: Income and subjective well-being across nations. Culture and subjective well-being, 185-218.

Dost, M. T. (2007). Üniversite öğrencilerinin yaşam doyumunun bazı değişkenlere göre incelenmesi. [Examining Life Satisfaction Levels of University Students in Terms of Some Variables] Pamukkale Üniversitesi Ĕgitim Fakültesi Dergisi, 22(2), 132-143.

Easterlin, R. A. (1974). Does economic growth improve the human lot? Some empirical evidence. Nations and households in economic growth, 89, 89-125. https://doi.org/10.1016/B978-0-12-205050-3.50008-7

Eren, A. T. (2008). Onkoloji Hemşirelerinin Işs Doyumunun ve Yaşam Doyumunun Incelenmesi. [Investigating Job Satisfaction and Life Satisfaction of Oncology Nurses] (Yüksek Lisans Tezi), Marmara Üniversitesi, İstanbul.

Ferrer-i-Carbonell, A. (2005). Income and well-being: An empirical analysis of the comparison income effect. Journal of Public Economics, 89(5-6), 997-1019. https://doi.org/10.1016/j.jpubeco.2004.06.003

Fosam, E. B., Grimsley, M. F. J., \& Wisher, S. J. (1998). Exploring models for employee satisfaction with particular reference to a police force. Total Quality Management \& Business Excellence, 9(2), 235-247. https://doi.org/10.1080/0954412989090

Frey, B. S., \& Stutzer, A. (2010). Happiness and economics: How the economy and institutions affect human well-being: Princeton University Press. https://doi.org/10.1515/9781400829262

Gençay, Ö. A. (2007). Beden eğitimi öğretmenlerinin iş doyumu ve mesleki tükenmişliklerinin bazı değişkenler açısından incelenmesi. [Investigating Job Satisfaction and Occupational Burnout of Physical Education Teachers in Terms of Some Variables] Kastamonu Eğitim Dergisi, 15(2), 765-780.

Green, S. B., \& Neil, J. (2005). Salkind. Using SPSS for Windows and Macintosh: Upper Saddle River, NJ: Pearson Prentice Hall.

Gündüz, B., Çapri, B., \& Gökçakan, Z. (2013). Mesleki tükenmişlik, işle bütünleşme ve iş doyumu arasındaki ilişkilerin incelenmesi. [Examining of the Relationships between Professional Burnout, Work Engagement and Job SAtisfaction] Ë̆itim Bilimleri Araştırmaları Dergisi, 3(1), 29-49.

Hart, P. M., Wearing, A. J., \& Headey, B. (1995). Police stress and well-being: Integrating personality, coping and daily work experiences. Journal of Occupational and Organizational Psychology, 68(2), 133-156. https://doi.org/10.1111/j.2044-8325.1995.tb00578.x

Herzberg, F., Mausnes, B., Peterson, R. O., \& Capwell, D. F. (1957). Job attitudes: review of research and opinion.

Judge, T. A., Piccolo, R. F., Podsakoff, N. P., Shaw, J. C., \& Rich, B. L. (2010). The relationship between pay and job satisfaction: A meta-analysis of the literature. Journal of Vocational Behavior, 77(2), 157-167. https://doi.org/10.1016/j.jvb.2010.04.002 
Kağan, M. (2010). Ankara İlindeki Devlet ve Özel İlköğretim Okulları ile Rehberlik ve Araştırma Merkezlerinde Çalışan Rehber Öğretmenlerin İş Doyumlarının İncelenmesi. [Research on School Counselors' Job Satisfactions Working at State and Private Elementary Schools, and Guidance and Research Centers in Ankara] Erzincan Üniversitesi Ĕ̈itim Fakültesi Dergisi, 12(1), 39-55.

Karababa, A. (2012). Psikolojik Danışmanlarda Olumlu Mükemmelliyetçilik ve Olumsuz Mükemmelliyetçilik Düzeylerinin Iş̧ Doyumu ve Yaşam Doyumunu Yordamadaki Rolü. (Yüksek Lisans) [Positive and Negative Perfectionism as Predictor of Job and Life Satisfaction], Pamukkale Üniversitesi Sosyal Bilimler Enstitüsü, Denizli.

Keser, A. (2005). İş Tatmini ve Yaşam Tatmini İlişkisi: Otomotiv Sektöründe Bir Uygulama. [The Relationship of Job Satisfaction and Life Satisfaction: A Case in Automative Sector] Çalışma Toplum Ekonomi ve Hukuk Dergisi, (7), 77-96.

Keser, A. (2006). Çalışma Yaşamında Motivasyon. [Motivation in Business Life] Bursa: Alfa Aktüel Yayınları.

Keskin, İ. (2008). İlköğretim Kurumlarında Görev Yapan Öğretmenlerin İş Tatmin Düzeyleri (Sultanbeyli Örneği). [Job Satisfaction Levels of Teachers Carrying on Their Duties in Elementary Schools: A Sultanbeyli Case] (Yüksek Lisans ), Yeditepe Üniversitesi, İstanbul.

Kline, R. B. (2015). Principles and practice of structural equation modeling. Guilford publications.

Kuruüzüm, A., \& Çelik, N. (2005). İkinci mertebeden faktör modeli ile öğretmen iş doyumunu belirleyen faktörlerin analizi. [Analyzing the Factors that Determine Teacher Job Satisfaction by Seond Order Factor Model] Hacettepe Üniversitesi Eğitim Fakültesi Dergisi, 29(29).

Kuzgun, Y. (2003). Meslek Rehberliği ve Danışmanlığına Giriş [Introduction to Occupational Guidance and Counseling]. Nobel Press. Ankara.

Lucas, R. E., \& Schimmack, U. (2009). Income and well-being: How big is the gap between the rich and the poor? Journal of Research in Personality, 43(1), 75-78. https://doi.org/10.1016/j.jrp.2008.09.004

Malasch, C., \& Leiter, M. P. (1997). The Truth about Burnout: How Organization Cause Personal Stress and what to Do about it. Jossey-Bass Incorporated, Publishers.

Malka, A., \& Chatman, J. A. (2003). Intrinsic and extrinsic work orientations as moderators of the effect of annual income on subjective well-being: A longitudinal study. Pers Soc Psychol Bull, 29(6), 737-746. https://doi.org/10.1177/0146167203029006006

McGregor, I., \& Little, B. R. (1998). Personal projects, happiness, and meaning: on doing well and being $\begin{array}{llllll}\text { yourself. Journal of personality and social psychology, } & \text { 74(2), } 494 .\end{array}$ https://doi.org/10.1037/0022-3514.74.2.494

Mersin, Y. (2007). Din Görevlilerinde Mesleki Doyum. (Yüksek Lisans), [Job Satisfaction in Religion Officials] Selçuk Üniversitesi Sosyal Bilimler Enstitüsü, Konya.

Nielsen, K., Yarker, J., Randall, R., \& Munir, F. (2009). The mediating effects of team and self-efficacy on the relationship between transformational leadership, and job satisfaction and psychological well-being in healthcare professionals: A cross-sectional questionnaire survey. International journal of nursing studies, 46(9), 1236-1244. https://doi.org/10.1016/j.ijnurstu.2009.03.001

Okyay, N. (2009). Emniyet teşkilatına bağlı okullardan mezun olup çevik kuvvet şube müdürlüğünde görev yapan polislerin psikolojik hizmet algıları, iş doyumu ve tükenmişlik düzeyinin incelenmesi. [Examining the Psychological Service Perception, Job Satisfaction and Burnout Levels of Police-School Resource Reinforcement Police] Yayınlanmamış Yüksek Lisans Tezi, Çukurova Üniversitesi Sosyal Bilimler Enstitüsü, Adana.

Özel, N. K. (2015). İş Doyumu ve Yaşam Doyumu Arasındaki İlişkinin Demografik Değişkenler Açısından İncelenmesi: Konaklama İşletmelerinde Bir Araştırma. (Yüksek Lisans), [Investigating the Relationship between Job Satisfaction and Life Satisfaction in Terms of Demographic Variables: A Research in Accomodation Businesses] Türk Hava Kurumu Üniversitesi, Ankara.

Ryan, R. M., \& Deci, E. L. (2001). On happiness and human potentials: A review of research on hedonic and eudaimonic well-being. Annual review of psychology, 52(1), 141-166. https://doi.org/10.1146/annurev.psych.52.1.141

Ryff, C. D. (1989). Happiness is everything, or is it? Explorations on the meaning of psychological well-being. Journal of personality and social psychology, 57(6), 1069. https://doi.org/10.1037/0022-3514.57.6.1069 
Ryff, C. D. (1995). Psychological well-being in adult life. Current directions in psychological science, 4(4), 99-104. https://doi.org/10.1111/1467-8721.ep10772395

Sevimli, F., \& Iscan, Ö. F. (2005). Bireysel ve is ortamina ait etkenler açisindan is doyumu. [Job Satisfaction in Terms of the Factors Related to Individual and Business Environment] Ege Academic Review, 5(1), 55-64.

Sezer, F. (2013). Psikolojik İyi Olma Durumu Üzerine Etkili Faktörler. Education Sciences, 8(4), 489-504.

Şişman, M., \& Turan, S. (2004). Bazı Örgüsel Değişkenler Açısından Çalışanların İş Doyumu ve Sosyal-Duygusal Yalnızlık Düzeyleri (MEB Şube Müdür Adayları Üzerinde Bir Araştırma). [A Study of Correlation between Job Satisfaction and Social-Emotional Loneness of Educational Administrators in Turkish Public Schools] Eskişehir Osmangazi Üniversitesi Sosyal Bilimler Dergisi, 5(1).

Sveinsdóttir, H., Biering, P., \& Ramel, A. (2006). Occupational stress, job satisfaction, and working environment among Icelandic nurses: A cross-sectional questionnaire survey. International journal of nursing studies, 43(7), 875-889. https://doi.org/10.1016/j.ijnurstu.2005.11.002

Teltik, H. (2009). Okul öncesi öğretmenlerinin mesleki yeterlilik algılarının iş doyumu ve tükenmişlik düzeyleriyle ilişkisinin belirlenmesi. [Determining the Relationship between Occopational Competence Perceptions of Pre-School Teachers and Job Satisfaction and Burnout Levels] Unpublished master's thesis, Marmara Üniversitesi, İstanbul.

Terry, D. J., Nielsen, M., \& Perchard, L. (1993). Effects of work stress on psychological well-being and job satisfaction: The stress-buffering role of social support. Australian Journal of Psychology, 45(3), 168-175. https://doi.org/10.1080/00049539308259135

Toker, B. (2011). Demografik değişkenlerin iş tatminine etkileri: İzmir'deki beş ve dört yıldızlı otellere yönelik bir uygulama. [The Effects of Demographic Factors on Job Satisfaction: An Application on Five and Four Star Hotels in Izmir] Doğuş Üniversitesi Dergisi, 8(1), 92-107.

Türkçapar, Ü. (2012). Beden Eğitimi Öğretmenlerinin Farklı Değişkenler Açısından İş Doyumu Düzeylerinin İncelenmesi. [Study of Job Satisfaction Level According to Different Variant among Physical Education Teachers] Gazi Üniversitesi Gazi Eğitim Fakültesi Dergisi, 32(2).

Waterman, A. S. (1993). Two conceptions of happiness: Contrasts of personal expressiveness (eudaimonia) and hedonic enjoyment. Journal of personality and social psychology, 64(4), 678. https://doi.org/10.1037/0022-3514.64.4.678

Willem, A., Buelens, M., \& De Jonghe, I. (2007). Impact of organizational structure on nurses' job satisfaction: A questionnaire survey. International journal of nursing studies, 44(6), 1011-1020. https://doi.org/10.1016/j.ijnurstu.2006.03.013

Witte, H. D. (1999). Job insecurity and psychological well-being: Review of the literature and exploration of some unresolved issues. European Journal of work and Organizational psychology, 8(2), 155-177. https://doi.org/10.1080/135943299398302

Wright, T. A., \& Cropanzano, R. (2000). Psychological well-being and job satisfaction as predictors of job performance. Journal of occupational health psychology, 5(1), 84. https://doi.org/10.1037/1076-8998.5.1.84

Yavuzer, Y., Karataş, Z., \& Gündoğdu, R. (2007). Eğitim Fakültelerinde Çalışan Yardımcı Doçentlerin Sürekli Kaygı ve İş Doyum Düzeylerinin İncelenmesi. [Investigating Permanenet Anxiety and Job Anxiety Levels of Assistant Professors Carrying on Their Duties in Education FAculties] Abant İzzet Baysal Üniversitesi Eğitim Fakültesi Dergisi.

Yiğit, R., Dilmaç, B., \& Deniz, M. E. (2011). İş ve Yaşam Doyumu: Konya Emniyet Müdürlüğü Alan Araştırması. [Job and Life Satisfaction: A Survey of Konya Police Department] Polis Bilimleri Dergisi, 13 (3).

\section{Note}

This study was presented as oral report in 1st. Eurasian Congress on Positive Psychology.

\section{Copyrights}

Copyright for this article is retained by the author(s), with first publication rights granted to the journal.

This is an open-access article distributed under the terms and conditions of the Creative Commons Attribution license (http://creativecommons.org/licenses/by/4.0/). 